bereavement. The voice may simply call the person's name. Normal people usually have no difficulty recognising the unreality of this experience.

Consultant Psychiatrist, Bethlem Royal Hospital,

JOHN CUTTING

Beckenham, Kent BR3 3BX

1 Malitz S, Kanzler M. Effects of drugs on perception in man. Res Publ Assoc Res Nerv Ment Dis 1976; $48: 35-53$.

2 Margo A. Hemsley DR, Slade PO. The effects of varying auditory input on schizophrenic hallucinations. $\mathrm{Br}$ f P sychiatry 1981;139:122-7.

3 Slade PO. The effects of systematic desensitisation on auditory hallucinations. Behav Res Ther 1972;10:85-91.

4 Sedman G. A comparative study of pseudohallucinations, imagery and true hallucinations. $\mathrm{Br} \mathrm{J}$ Psychiatry 1966;122:9-17
5 Alpert $M$, Silvers KN. Perceptual characteristics distinguishing auditory hallucinations in schizophrenia and acute alcoholic psychoses. Am f Psychiatry 1970;127:298-302.

6 Taylor P, Fleminger JJ. The lateralization of symptoms in schizophrenia. $\mathrm{Br} f \mathrm{Med}$ Psychol 1981;54:59-65.

Critchley EMR, Denmark JC, Warren F, Wilson KA. Hallucinatory experiences of prelingually profoundly deaf schizophrenics. Br $\mathcal{F}$ Psychiatry 1981;138:30-2.

8 Starker S, Jolin A. Imagery and hallucinations in schizophrenic patients. 7 Nerv Ment Dis 1982;170:448-51.

9 Schneider K. Clinical psychopathology. New York: Grune and Stratton, 1959.

10 Birchwood $\mathrm{M}$. Control of auditory hallucinations through occlusion of monoaural auditory input. Br $\mathcal{F}$ Psychiatry 1986;149:104-7.

11 Falloon IRH, Talbot RE. Persistent auditory hallucinations: coping mechanisms and implications for management. Psychol Med 1981;11:329-39.

12 Gross MM, Halpert E, Sabot L, Polizos P. Hearing disturbances and auditory hallucinations in the acute alcoholic psychoses: tinnitus, incidence and significance. $\mathcal{F}$ Nerv Ment Dis 1963;137: 455-6

13 Saravay SM, Pardes H. Auditory elementary hallucinations in alcoholic withdrawal psychosis. Arch Gen Psychiatry 1967;16:652-8.

14 Penfield W, Perot P. The brain's record of auditory and visual experience. Brain 1963;86:595-696.

\title{
Diet and dermatology
}

\section{Food explains some, but by no means all, skin conditions}

"Could it be something I've eaten doctor?" is guaranteed to provoke a sigh from most doctors. Even so, although many dietary hypotheses have now been discarded, ${ }^{1}$ diet does cause some skin diseases and may modify others.

Too much or too little food may affect the skin. Some obese patients with insulin resistance and hyperinsulinaemia develop acanthosis nigricans and skin tags, ${ }^{23}$ which may be due to the binding of insulin to peptide growth factors. ${ }^{+}$The same cellular defect may predispose to both obesity and acanthosis nigricans, but diet is probably at least partly responsible because the insulin resistance responds to fasting. ${ }^{5}$ Too much of a single food constituent may cause problems. Hypervitaminosis A causes diffuse alopecia and hypercarotenaemia discolours the palms and soles orange. This occurs usually in slimmers having low calorie diets who eat too many carrots and oranges. ${ }^{6}$

Chronic starvation deficiency of protein and calories causes a scaly rash, and the hair tends to become dry and sparse. Kwashiorkor produces a scaling of the skin, which often takes on the glazed appearance of adherent enamel flakes, and a characteristic reddish discoloration of black hair. The hair may also show the "flag sign," with alternating dark and light bands in individual hairs, which is due to intermittent protein deficiency. Measurement of hair growth has been suggested as useful for assessing nutritional state, particularly for proteins. ${ }^{8}$ Patients with anorexia nervosa develop dry skin, lanugolike body hair, thinning of the scalp hair, and brittle nails. ${ }^{9}$ The cutaneous manifestations of specific deficiencies of various vitamins and minerals provide classic examples of dietary dermatoses. ${ }^{10-13}$

Food and drink may be either inherently toxic or toxic as a result of contaminants such as fungi or added chemicals. Alcohol is a cutaneous vasodilator, and the Chinese and Japanese are particularly susceptible to alcohol induced flushing. ${ }^{1+}$ Chillies and red peppers also produce flushing and sweating by a pharmacological action. ${ }^{15}$ Ergotism, characterised by severe Raynaud's phenomenon leading to digital gangrene, is due to eating bread made from rye infected with a fungus. An example of a dermatosis caused by chemical contamination occurred in Turkey, when the ingestion of wheat treated with a fungicide, hexachlorobenzene, resulted in many cases of porphyria cutanea tarda. ${ }^{16}$

Urticaria is commonly due to ingested food allergens, but the gluten enteropathy of dermatitis herpetiformis is a more subtle example. If gluten is avoided and the bowel recovers completely the skin disease may go into complete remission. ${ }^{17}$

Idiosyncratic susceptibility to dietary factors may be commoner than appreciated. Some cases may be due to interactions with systemic medication-for example, the severe alcohol induced flushing in some patients who take chlorpropamide ${ }^{18-20}$ and the reaction to cheese or pickles in patients taking inhibitors of monoamine oxidase. Other reactions may be due to anatomical abnormalities such as the flushing that accompanies the postgastrectomy dumping syndrome. Some idiosyncratic reactions-for example, the urticaria and bronchospasm caused by bisulphites used to keep fruit and vegetables fresh - may be mediated by neural activity as the results of tests for allergy are negative.and the adverse reaction is blocked by atropine. ${ }^{21}$ The Chinese restaurant syndrome, in which similar symptoms occur after eating sodium glutamate, seems to be mediated by the transient release of compounds similar to acetylcholine..$^{22} 23$

Clinical observations have led to many attempts to improve skin disease by changing the diet, though few have stood the test of time. Some improvements may be due to idiosyncratic reactions. Many patients think, for example, that chocolate makes their acne worse despite several studies showing that it does not affect its course. ${ }^{2425}$ The value of exclusion diets for treating atopic eczema is also controversial ${ }^{26}{ }^{27}$; though these are widely used, it seems that women's magazines have more success with them than doctors.

The use of fatty acid supplements to treat atopic eczema is another idea that was fashionable in the 1930s, died out in the $1950 \mathrm{~s}$, and has recently been exhumed in the light of increasing knowledge of fatty acid and eicosanoid metabolism. ${ }^{28}$ Patients with atopic eczema have low concentrations of essential fatty acid metabolites in their plasma, ${ }^{29}$ and some plant and fish oils are particularly rich in these compounds and their precursors. Evening primrose oil and borage, for example, are rich in $\gamma$-linolenic acid, which is depleted in atopic eczema. Several trials have shown that oral evening primrose oil in large doses has beneficial effects in eczema, ${ }^{28-33}$ and meta-analysis of several controlled trials has shown that the clinical improvement correlates with the increase in plasma fatty acid metabolites after such treatment. ${ }^{34}$ Similar studies have shown modest benefit from dietary supplements with fish oil in psoriasis and eczema. ${ }^{28}$ The exact mechanism of these clinical changes is uncertain, but a better understanding of the intermediary metabolism of essential fatty acid metabolites and trace metals such as zinc might pave the way 
for better suppression of inflammation by dietary modulation.

Reader and Consultant Dermatologist,

J L BURTON

Bristol Royal Infirmary,

Bristol BS2 8HW

1 Burton JL. Diet and dermatology in 1888: the influence of H Radcliffe Crocker. Br f Dermatol 1988;119:471-8.

Kahn CR, Flier JS, Bar RS, et al. The syndrome of insulin resistance and acanthosis nigricans: insulin receptor disorders in man. $N$ Engl f Med 1976;294:739-45.

3 Flier JS. Metabolic importance of acanthosis nigricans. Arch Dermatol 1985;121:193-4.

4 Blundell TL, Bedarkian S, Humbel RE. Tertiary structures, receptor binding and antigenicity of insulin-like growth factors. Federation Proceedings 1983;42:2592-7.

5 Peters ET, Stuart CA, Prince MJ. Acanthosis nigricans and obesity: acquired and intrinsic defects in insulin action. Metabolism 1986;35:807-13.

6 Bilimoria S, Keckes $\mathrm{K}$, Williamson D, Rowell NR. Hypercarotenaemia in weightwatchers. Clin Exp Dermatol 1979;4:331-4.

MacLaren DS. Skin in protein energy malnutrition. Arch Dermatol 1987;123:1674-6.

8 Sims RT. The measurement of hair growth as an index of protein synthesis in malnutrition. Brf Nutr 1968;22:229.

Gupta MA, Gupta AK, Haberman HF. Dermatologic signs in anorexia nervosa and bulimia nervosa. Arch Dermatol 1987;123:1386-90.

10 Barthelemy $\mathrm{H}$, Chouvet $\mathrm{B}$, Cambazard $\mathrm{F}$. Skin and mucosal deficiencies in vitamin deficiency. 7 Am Acad Dermatol 1986; 15:1263-74.

11 Roe D. Nutrition and the skin. Contemporary issues in clinical nutrition. Vol 10. New York: Liss, 1986 12 Fraker BJ, Jardieu P, Cook J. Zinc deficiency and immune functions. Arch Dermatol 1987;123: 1699-701.

13 Weismann K. Nutrition and the skin. In: Rook A, Wilkinson DS, Ebling JFG, Champion RH Burton JL, eds. Textbook of dermatology. 4th ed. Oxford: Blackwell Scientific Publications, Burton JL, eds.

14 Wolff PH. Ethnic differences in alcohol sensitivity. Science 1972;175:449-50.

15 Wilkin JK. Flushing reactions. In: Champion RH, ed. Recent advances in dermatology. Vol 6 Edinburgh: Churchill Livingstone, 1983:158-87.
16 Cripps DJ. Porphyria turcica, twenty years after hexachlorobenzene intoxication trch Dermutul 980;116:46-50

17 Hall RP. Dietary management of dermatitis herpetiformis. Arch Dermatol 1987;123:1378-80.

18 Barnett AH, Pyke DA. Chlorpropamide-alcohol induced flushing and large vessel disease in non-insulin dependent diabetes mellitus. Br.Med f 1980;281:261-2

19 Barnett AH, Spiliopoulos AJ, Pyke DA. Blockade of chlorpropamide-alcohol flushing by indomethacin suggests an association between prostaglandins and diabetic vascular complications. Lancet 1980;ii:164-6.

20 Kobberling J, Weber M. Facial flush after chlorpropamide-alcohol and enkephalin. Lance $1980 ;$ i:538-9.

21 Settipane G. Adverse reactions to sulfite in drugs and foods. F Am Acad Dermatol 1984:10:1077-80 22 Ghadimi H, Kumar S, Abaci F. Studies on monosodium glutamate ingestion; 1. Biochemical explanation of the Chinese restaurant syndrome. Biochem Med Metab Biol 1971;5:447-56.

23 Reif-Lehrer L. Possible significance of adverse reactions to glutamate in humans. Federation Proceedings 1976;35:2205-11.

4 Plewig G, Kligman AL. Acne morphogenesis and treatment. Berlin: Springer-Verlag, 1975:270-1.

25 Fries JH. Chocolate-a review of published allergic and other deleterious effects, real and presumed. Ann Allergv 1978;41:195-207.

26 Ather in DJ. Role of diet in treating atopic eczema: elimination diets can be beneficial. Br Med 1988;297:1458-60.

27 Allen R. Role of diet in treating atopic eczema; dietary manipulation has no value. $\mathrm{Br}$.Med $\mathcal{J}$ 1988;297:1459-60

28 Burton JL. Dietary fatty acids and inflammatory skin disease. Lancet 1988;i:27-31.

29 Mankı MS, Horrobin DF, Morse NL, Wright S, Burton JL. Essential fatty acids in the plasm phospholipids of patients with atopic eczema. Br F Dermatol 1984;110:643-8.

30 Lovell CR, Burton JL, Horrobin DF. Treatment of atopic eczema with evening primrose oil. Lancet 1981; ; 278 .

31 Wright S, Burton JL. Oral evening primrose seed oil improves atopic eczema. Lancet 1982;ii: $1120-2$.

32 Schalin-Karrila M, Mattila L, Jansen CT, Uotila P. Evening primrose oil in the treatment of atopic eczema: effect on clinical status, plasma phospholipid fatty acids and circulating blood prostag

33 Sugai $T$. Clinical evaluation of oral evening primrose oil in atopic patients. Skin Research 1987;29:330-8.

34 Morse PF, Horrobin DF, Stewart C, et al. Meta-analysis of placebo-controlled studies of the efficacy of Epogam in the treatment of atopic eczema: relationship between plasma essential fatty acid changes and clinical response. $B r f$ Dermatol (in press)

\title{
Health needs of the homeless
}

\author{
Homes are cheaper than bed and breakfast
}

Half a million pounds is spent each week on bed and breakfast accommodation for London's homeless. ${ }^{1}$ Most of the families who live in this depressing, dreary way have become homeless because they cannot afford to rent or buy and local authorities cannot provide any alternative. In the past 25 years the number of dwellings available for rent in Britain has dropped by one million. The number of households in temporary accommodation has doubled since 1981 and reached 30100 in England in December 1988.

Among the many problems of the homeless is getting medical care when they need it, and this issue has now been examined in a joint report by the Health Visitors' Association and the General Medical Services Committee of the BMA. Part III of the Housing Act 1985 requires local authorities in England and Wales to house homeless people with special needs-children, pregnant women, the elderly, the disabled, and the mentally ill. ${ }^{3}$ The number of homeless families offered help by local authorities in England has more than doubled since 1979 and reached 116060 last year. This does not take into account those who applied for but were refused helpmore than 400000 households since 1982 .

People living in overcrowded temporary accommodation face many health risks. ${ }^{+}$Children come down repeatedly with diarrhoeal illnesses and chest infections, and homeless women are twice as likely to have problems and three times as likely to be admitted to hospital during pregnancy as other women. Accidents and fires are substantial hazards. Depression and stress among parents may predispose them to abuse their children. Health visitors are concerned about the nutrition of people in bed and breakfast accommodation. ${ }^{5}$ Many families have to vacate the premises between $10 \mathrm{am}$ and $4 \mathrm{pm}$, and when they are allowed back they have to share inadequate cooking facilities with many other families.

Mothers and young children are among the largest consumers of primary health care, and when their health is endangered by their living conditions it becomes even more important that they have easy access to high quality health services. Some general practitioners are reluctant to take homeless people on to their lists. Families in temporary accommodation may hope that it will be for a short time and may fail to register with local general practitioners or do so only as temporary residents, in which case their notes will not be forwarded to their new doctor. Such families may then use accident and emergency departments when they need medical help, but this is not the best way to provide continuing care for families with young children and is a waste of those resources.

The report emphasises the need for more information about homeless families and highlights the problems faced by general practitioners in areas where there are many dwellings in multiple occupation. It suggests that each district health authority should have a liaison officer for homeless persons who has responsibility for informing health visitors about the arrival of a new family, arranging transfer of the relevant notes, and informing the family practitioner committee about the number of families in temporary accommodation. Another possibility is the wider use of client held records to reduce some of the problems caused by the frequent transfer of notes.

The report calls on the government to consult with the BMA about ways of removing financial and organisational barriers that inhibit homeless families from gaining access to primary health care. It suggests that general practitioners should receive a registration fee for new patients and that patients accepted on to a list as temporary residents should count towards the list size. The recommendations in the report are an attempt to improve the provision of primary health care to homeless families, but the real answer to these problems is to provide permanent homes at affordable rents.

Since 1980 the government has encouraged council tenants 